\title{
SENATOR GRIMES BACKED ERICSSON
}

Out of the rich corn belt of America there has come much to stimulate and glorify the age of steel, and especially in men to direct that epochal revolution in which the king of industrial metals replaced the timbered oaks as chief reliance for defense in naval warfare.

There is real reason why the state of Iowa commenced long ago to build up at the seat of government a special naval museum and to collect the materials of Iowa's part in the nation's first line of defense. Iowa has been navy conscious almost from the first. It was once suggested that perhaps the waves of the cornfields suggested the waves of the sea and gave Iowa boys their love of the wide expanses of the ocean.

Ours must be a great maritime nation. Heaven has ordained that it should be such, and we could not make it otherwise if we would.

So declared an able Iowa man on the floor of the United States senate more than eighty-five years ago. He was defending the navy in its exploits in the war then in progress. He was to some extent responsible for what was then being done. He was chairman of the senate committee on naval affairs. He had reason to realize the supreme importance of the navy in the defense of any country having a shore line open to the world. He had just said:

I am anxious that the people of this entire country may feel that the exploits of the Navy, wherever performed, are their exploits, that its glory is their glory, and that while they are taxing themselves to support it they are supporting the right arm of the national defense. I desire the citizens of the most remote frontier to feel that he is equally protected and equally honored by the brave deeds of our naval officers with the citizens of the Atlantic coast.

He went on to give assurance to the citizens of Iowa and Minnesota that they are as effectually defended in their liberties by the operations of the navy as the people of the coastal states. He discounted the theory that the army must be given credit chiefly for any national 368 
defense. "History teaches us," he said, "that every nation that had depended upon a navy for protection has been comparatively free by the side of those that placed reliance upon armies."

\section{Navy Chairman from Iowa Corn Fields}

The speaker was Sen. James W. Grimes of Iowa. The occasion was the naval events of the early part of the year 1862 at Hampton Roads and on the Mississippi river, which was a turning point in the Civil war. Mr. Grimes had been governor of Iowa. He was serving his second term as United States senator. $\mathrm{He}$ had been placed at the head of the senate committee on naval affairs at the beginning of the war and served as chairman until the close of the war. Therefore he was thrown into close official connection with the navy in all phases. Perhaps, also, his interest was enhanced by the fact that Admiral Walker was his favorite nephew. It seemed to many entirely inappropriate that the handling of navy affairs, on behalf of the senate, should be entrusted to a senator from an interior state; but Senator Grimes held the confidence of his associates and all the naval men, and when near the close of the war he asked to be relieved from the chairmanship of the naval committee, such was the protest in the senate that he remained as the chairman.

The occasion for recalling the great work of an Iowa senator in connection with the navy is given by a historical item found on the cover of a magazine, "Steelways," published by the Iron and Steel institute, New York, for May 1947, beneath a picture showing the battle between the Merrimac and the Monitor, as follows:

"The day of wooden navies, already on the wane, was definitely done when darkness fell on Hampton Roads Narch 8, 1862, twelve hours before the USS Monitor went into action. The Merrimac, the Confederate ironclad renamed the Virginia, had already proved her superiority over wooden fighting craft while the celebrated 'cheesebox' was floundering south from New York, al- 
most sinking twice on the way. The blockading Union fleet was disorganized when the Monitor arrived at Newport News. Two ships had been sunk. Two more had been driven aground and the remainder scattered. Next morning when the slope-sided Virginia steamed out to finish the job, the Monitor took up the fight. The two ships battled for four hours, with sides touching much of the time. Neither ship was damaged in the slugfest. One man was wounded abroad the Monitor. $\mathrm{He}$ was the only casualty. The evidence is hopelessly confused as to which ship broke off the engagement and each side claimed the victory. The Virginia had struck a damaging blow against the northern fleet. The Monitor stopped the Virginia temporarily. Final decision was the proved battle superiority of iron over wood."

\section{A Turning PoInt in History}

It is not too much to say now that the day in early 1862 when the awkward Merrimac, or Virginia, proved that iron covering would make a battleship irresistable was the darkest day in American history; and that the following day, when the little Monitor demonstrated thai. an iron turret with a safety box for navy guns was the real turning point in the war to save the Union. The whole story is one of the most thrilling in all American history. Admiral Porter, in his Naval History of the Civil war, referred to the events of the first day, saying:

Thus closed one of the most memorable days of the Civil war, a day which carried gloom and sorrow to the hearts of all loyal citizens. The authorities at Washington were dismayed, and it appeared to those most familiar with the circumstances that this was the crisis of the Union cause.

The people of the seceded states did not overlook the matter. Admiral Porter says of them:

All through the south there were scenes of rejoicing; bonfires blazed on the hilltops, and everywhere the Confederates expected that the next news would be the total destruction of the Federal fleet at Hampton Roads and the advance of the Merrimac to Washington.

There was not a decisive victory on the day of the engagement of the Monitor with its monster adversary, 
but it dampened the enthusiasm of those who had planned for the Merrimac to advance upon and take the national capital. Neither vessel ever did anything further. But the whole series of events there and later on the waters of the Mississippi and its tributaries made it plain that iron and steel had replaced wood for navy use.

Here comes in the working relation of the vigorous young senator for the corn lands of Iowa and the unorthodox engineer with a vision who had made good on what others had talked about. There is no doubt that Senator Grimes, as chairman of the senate committee on Naval Affairs, was in full sympathy with the plans of John Ericsson in the building of an ironclad fighting vessel with a revolving turret. On January 19, 1861, Senator Grimes had introduced a resolution directing the Secretary of the Navy to furnish detailed estimate of the expense of building a steel or ironclad gunboat, and soon thereafter he advocated the construction of screw sloops-of-war of the second class to defend American harbors. This was more than a year before the Hampton Roads incidents. Soon after those incidents, namely on March 11, 1862, he said in the senate:

There is a perfect panic in our northern commercial cities. New York seems to think that in a few days the Merrimac is going to be seen sailing up Broadway! They have had, perhaps, some reason for excitement, growing out of the egress of the Merrimac from Elizabeth river; but they ought to remember that the government has done something, and is doing something, to protect the commerce of these cities against any danger that may arise from the Merrimac coming out again. It is well enough to know exactly what the department has done. In the first place we have the Monitor. She has been tested, and in such manner as no English or French vessel has been tested. We know exactly her capacities in actual warfare and her seagoing capacities. We have, therefore, a basis upon which to build a system. If we go on and improve upon that foundation which the Monitor and her success seem to have laid, then we can establish something that will be creditable and useful to the country. The Monitor was built by Mr. Ericsson at his own risk. He entered upon the contract, and the government did not agree to receive the vessel from him until she had been tested. She was on the way round to be tested upon the batteries at Pig 
Point on the Potomac when the Merrimac came out from her retreat...

The strange situation, that of a privately built and privately owned and operated gunboat winning the decisive naval battle of the war, is in part explained by the fact that Mr. Ericsson, the inventor, was a rank outsider, and also that the chairman of the naval affairs committee, Mr. Grimes, was also supposed to be an amateur in naval matters, because of living a thousand miles from any ocean or harbor. When the war started, the United States had only eight seaworthy vessels in the navy, and before it closed the effective force consisted of five or six hundred actual fighting craft. Appropriations for these vessels were made with the approval of congress. Senator Grimes held the key position as to all naval projects.

\section{SENATOR GRIMES DEFENDED NAVY}

Despite progress made and success achieved there were critics of the navy. In February, 1865, there was before the senate a proposal to create a board of admiralty for the navy. Senator Grimes opposed and came to the defense of the navy. There had been criticism in the matter of building light-draught vessels. Senator Grimes said:

In regard to the light-draught ironclads, the facts are very simple. We had a board, in 1861, composed of three superior officers in the navy, to determine the character of the vessels that should be built with the million and a half dollars appropriated in July of that year. They reported in favor of three different classes of vessels: the Ironsides, which is an excellent vessel; the Galena, which has turned out to be a failure; and they said to Mr. Ericsson who proposed to build the original Monitor, that he might build that vessel for a given sum of money, a small price, and run his own risk upon her; if she turned out to be a success the government would take her, and if otherwise it would not. That Monitor, at the time she fought the Merrimac, and relieved us of the great weight that rested upon every man here in Washington after the destruction of the Congress and Cumberland, was not the property of the United States, but belonged to John Ericsson and the men who were associated with him in building her. 
So it was not the fault of the Iowa senator that in order to prove his idea was right, Inventor Ericsson had to call upon friends to help him in demonstrating that the monitor type of vessel was the one for the future. A navy board of experts had practically condemned the idea before it was tried. But it was accepted at a cost of only $\$ 275,000$, and many of the vessels constructed for the defense of the nation followed the plans of the Monitor, though subjected to innumerable changes.

The senator from Iowa is entitled to credit along with the bold inventor for saving the Union and for having revolutionized naval warfare at a critical time. That Captain Ericsson was not unmindful of the service of his Iowa friend is shown by a letter to Grimes after one of the latter's speeches, saying:

It would, indeed, prove a great stimulus for exertion, if all who labor for the public good could have their deeds placed before the country in such striking and eloquent language as characterized your speech.

Senator Grimes quite properly had much influence with the administration of national affairs during the Civil war. As governor of Iowa he had friendly correspondence with Abraham Lincoln in 1857 when the two lived in judicial districts that adjoined. When the nomination for the presidency had been made he wrote his wife in 1860 :

The nomination of Lincoln strikes the mass of the people with great favor. $\mathrm{He}$ is universally regarded as a scrupulously honest man, and a genuine man of the people.

When Abraham Lincoln became president, Senator Grimes had been full two years in the senate and was on the committee on naval affairs. His first speech was in defense of Iowa from an unjust accusation of having passed laws contrary to the constitution. He watched with anxiety the expiring days of the administration before Lincoln was given the reins. He wrote his wife, giving a picture of the chaos that reigned:

General Cass has resigned as well as Mr. Cobb. The whole cabinet is tumbling to pieces and in what remains is without in- 
fluence. Mr. Buchanan it is said, about equally divides his time between praying and crying. Such a perfect imbecile never held office before. When Cobb resigned, he sent him a letter, saying that he was going home to Georgia, to assist in dissolving the Union, and breaking up the government; and Buchanan replied to the letter, and complimented Mr. Cobb, as you have seen.

It was in this confusion that Senator Grimes had come to membership on the naval affairs committee. He had early turned his attention to national defense. He had become much interested in the work done at West Point. $\mathrm{He}$ became familiar with conditions at Annapolis. $\mathrm{He}$ later defended both schools from the aspersion that under the guidance of southern commandants and teachers they had been conducted as schools of treason. After the inauguration of President Lincoln, Grimes placed himself in contact with Under Secretary G. B. Fox, who was intensely interested in the quick development of a national navy for the defense of the country. It is said that during a large part of the war, Grimes and Fox held conversations at least three times a week, and thus the Iowa senator was better informed on naval matters than any other senator.

Senator Grimes became an early and earnest advocate of better pay for the navy officers and men, for a modern system of handling promotions and advancements, and in general for the lifting of the navy to a higher plane. He advocated that officers in the marine corps be selected from graduates of the naval academy.

\section{Grimes ENTITLED TO A MONUMENT}

Someone ought to take the initiative for a monument on the naval academy campus at Annapolis to James W. Grimes as the man who saved that institution for the Maryland city.

As a matter of fact the naval academy was never, by law, located at Annapolis, or anywhere else for that matter. Some instructors in naval affairs, following the advice of Alexander Hamilton, simply took possession of a fort and used it for a school-hence the naval academy. But during the Civil war a pronounced move- 
ment was under way to move it to Newport, or Perth Amboy, or some place not so southern as in Maryland. At one time the learned army officers had taken over the academy, and Grimes rushed to the scene and had the academy temporarily moved to Fort Adams, Newport, R. I. But when the turn of war had changed, he insisted upon the academy going back to Annapolis. He declared that "a more favorable position could not be found for a naval academy, and more satisfactory accommodations for the students could not be devised than existed at Annapolis at the breaking out of this rebellion," and added that "I think I hazard nothing in saying that no institution for professional training was ever conducted with more eminent success."

James W. Grimes, the senator from the corn country of Iowa, was in fact in position to make good on his convictions, as he had been when he encouraged Capt. John Ericsson to demonstrate that iron and steel had relegated oak wood to a secondary place in naval construction.

\section{THE INDIAN CALLED IT "AH YO I"}

The beauty of the woodland areas of Iowa were often pointed out by Edgar R. Harlan, and their utility to both Indian and white man appreciated. In an article about the Indians of Van Buren county he said this was "what was meant when a Sac or Fox spoke of the region in his word 'ah yo i', 'this is the place'-to worship, to trap, to hunt, to bathe, to be a creature among his brother creatures of his Manitou."

\section{PIONEER SCHOOLHOUSE PRESERVED}

Within a few miles of Story City, Iowa, stands a pioneer schoolhouse, preserved from early days, but no longer used for school purposes. It is upon the same spot where it was built in 1860 . The district was organized in 1858, but the earlier terms were taught in private homes of the community. 
Copyright of Annals of Iowa is the property of State of Iowa, by \& through the State Historical Society of Iowa and its content may not be copied or emailed to multiple sites or posted to a listserv without the copyright holder's express written permission. However, users may print, download, or email articles for individual use. 